膀胼癌患者末梢血のリンパ球キラー活性

\author{
信州大学泌尿器科 \\ 岡根谷 利一 小 川 秋 實
}

\title{
KILLER ACTIVITIES OF PERIPHERAL BLOOD MONONUCLEAR CELLS IN PATIENTS WITH BLADDER CANCER
}

\author{
Toshikazu Okaneya and Akimi Ogawa \\ Department of Urology Shinshu University School of Medicine \\ (Director: Porf. Akimi Ogawa, M.D.)
}

Killer activity of peripheral blood mononuclear cells with or without adding interleukin-2 in vitro was measured in 12 patients with superficial bladder cancer, 12 patients with invasive bladder cancer and 13 adult healthy controls. Cultured cell lines, K562, Raji and T-24 (bladder carcinoma), were served as target cells. Killer activity was measured by a 4 -hour ${ }^{51} \mathrm{Cr}$-release assay. Mononuclear cells from patients with superficial bladder cancer had a significantly higher natural killer activity against K562 and T-24 (50.8 $\pm 6.2 \%$ and $15.0 \pm 9.5 \%$, respectively) than those from patients with invasive bladder cancer $(28.2 \pm 8.0 \%, 9.5 \pm 8.8 \%)$ and than those from controls $(33.0 \pm 8.9 \%, 3.0 \pm 2.5 \%)$. When cultured in vitro with recombinant interleukin-2, mononuclear cells from patietns with superficial bladder cancer developed a significantly higher killer activity against K562, Raji and T-24 (58.4 $\pm 5.8 \%$, $40.1 \pm 15.9 \%$ and $49.5 \pm 10.5 \%$, respectively) than those from patients with invasive bladder cancer $(48.1 \pm 5.9 \%, 27.9 \pm 13.8 \%$ and $40.1 \pm 7.4 \%)$ and than those from controls $(48.9 \pm 6.7 \%, 30.3 \pm 10.5 \%$ and $39.5 \pm 3.8 \%)$. Flow cytometric analysis showed that there was no significant difference in surface markers between mononuclear cells from patients with superficial bladder cancer and those from patients with invasive bladder cancer. These results suggest that tumor immunity may participate in development and progresion of bladder cancer.

Key words: bladder cancer, natural killer activity, IL-2 induced killer activity

\begin{abstract}
要旨：末梢血単核細胞のナチュラルキラー（NK）活性とインターロイキン 2 添加により誘導されたキ ラー活性を表在性膀胱癌患者, 浸潤性膀胱癌患者扰よび健康人の間で比較した。キラー活性は, 標的細 胞として K562, Raji, T-24の株細胞を用いてクロム放出試験で測定した。表在性膀胱癌患者では対照健 康人に比べ $\mathrm{NK}$ 活性が増強しており，インターロイキン 2 添加によるキラー活性の誘導も著明であっ た。一方, 浸潤性膀脂癌患者では NK 活性もインターロイキン 2 添加によるキラー活性の誘導も対照健 康人と有意差が無かった。表在性膀胱癌患者と浸潤性膀胱癌患者の間にリンパ球表面マーカーには差が 無かった。
\end{abstract}

キーワード：膀胱癌, NK 活性, IL-2誘導キラー活性

\section{緒}

結核菌の生菌である BCG の膀胱内注入療法は表在 性膀胱癌や膀胼上皮内癌の治療および再発予防に有効 性が認められている1) 3). その作用機序の詳細は解明 されていないが，尿中に interleukin 2（以下 IL2 と略 す)の産生がみられたり ${ }^{4)}$, 局所的および全身的に抗腫
瘍免疫能を賦活化していることが明らかにされつつあ $3^{1) \sim 5)}$. 一方, BCG 膀脱内注入療法は浸潤性膀胱癌に 対しては無効である。その理由として浸潤性膀胖癌と 表在性膀胀癌では免疫学的に異なった状態にあり，ま た各種サイトカインに対する応答能にも差があるので はないかと考兄らる。この点を明らかにするために, 
われわれは，末梢血リンパ球の natural killer 活性と recombinant interleukin-2（以下 rIL-2と略す）による キラー活性の誘導について検討した.

\section{対象および方法}

\section{1）対象患者}

術前の表在性膀胱癌患者 12 例 ( $\mathrm{pT}_{1} 4$ 例, $\mathrm{pTa} 8$ 例) 之浸潤性膀胱癌患者 12 例 $\left(\mathrm{pT}_{2} 3\right.$ 例, $\mathrm{pT}_{3} 6$ 例, $\mathrm{pT}_{4} 3$ 例)を対象とした.表在性膀脱癌組織の grade は grade 1 が 6 例, grade 2 が 2 例, 両者の混在が 4 例であった.

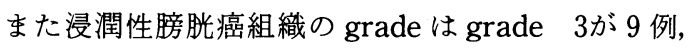
grade 2 と grade 3 の混在が 3 例であった。

患者の平均年柃は表在性腫瘍が69.5 腫瘍が69.6土10.5歳（平均士標準偏差）であった。対 照人は成人健康人 13 例（平均年齢 $55.9 \pm 16.1$ 歳）とし た.

2) 方法

(1) 完全培養液の作成

組織培養用培地 RPMI1640に非働化ウシ胎児血清 （以上 Flow Labo.）を10\%の割合に加光，さらにゲン タマイシン $16 \mathrm{mg} / l$ を加えて完全培養液を作成した。

(2) エフェクター細胞の調整

末梢血を完全培養液で希釈後 Ficoll-Paque に重層, $400 \mathrm{G}$ で30分間遠沈後単核細胞を分離, 完全培養液で 3 回洗浄後 $5.0 \times 10^{5} / \mathrm{ml}$ となるよう調整した. この標本 の半数は直ちに NK 活性測定のため細胞障害性試験 に供し, 残りには rIL-2 (TGP-3, 武回薬品) $2 \mathrm{u} / \mathrm{ml}$ を 添加した 24 穴平底プレート (Nunc)にて $37^{\circ} \mathrm{C}, 5 \% \mathrm{CO}_{2}$ 下で培養した。

\section{(3) 標的細胞の調整}

K562（人赤芽球性白血病株細胞）, Raji (Burkitt lymphoma 由来細胞で NK 非感受性), おょび T$24(\text { 人膀胼癌株細胞 })^{6}$ を用いた。 K562, Raji は培養液 を半量交換して24時間培養後 1 回洗浄した。T-24は $0.25 \%$ トリプシン (半井化学) と $0.02 \%$ EDTA（阪大 微研）の混合液にて細胞を剥離後, 完全培養液で 3 回 洗浄した。それぞれ $100 \mu \mathrm{Ci}$ の $\mathrm{Na}_{2}{ }^{51} \mathrm{CrO}_{4}$ (New England Nuclear, Boston, MA）を加えて60分培養し， その後完全培養液で 3 回洗浄後, $1 \times 10^{5}$ 個 $/ \mathrm{ml}$ に調整 した.

(4) Natural Killer (NK) 活性 ${ }^{7)}$ の測定

${ }^{51} \mathrm{Cr}$ でラベルした K562, Raji, T-24細胞のそれぞれ の $1 \times 10^{4}$ 個を完全培養液 $0.1 \mathrm{ml}$ に浮遊させ 96 穴丸底 プレート(Nunc, Roskilde, Denmark)に分注し，さ らにェフェクター細胞をェフェクター細胞・標的細胞
比が20：1 となるよう0.1ml 完全培養液に調整して標 的細胞に加光，プレートを $100 \mathrm{G}$ で 3 分間遠心後, $37^{\circ} \mathrm{C}$ $5 \% \mathrm{CO}_{2}$ 下で 4 時間培養した。 その後プレートを $400 \mathrm{G}$ で 5 分間遠心し上清をマイクロピペットを用いてそれ ぞれ採取し， $\gamma$ シンチレーションカウンター(Packard Instrument Co., Downers Grove, IL) で計数して実 験解離値とし, 同時に ${ }^{51} \mathrm{Cr}$ でラベルした標的細胞浮遊 液の上清を計数して自然解離値とした。また標的細胞 を直接計数したものを最大解離値とし，NK 活性は次 式により求めた。

\section{$\frac{\text { 実験解離値一自然解離値 }}{\text { 解離值一自然解離値 }} \times 100(\%)$}

測定は全て重複して行ない，その平均値を求めた。 なお, 自然解離值は最大解離値の $10 \%$ を越えなかった。

(5) rIL-2添加により誘導されるキラー活性 ${ }^{8)}$ の測定

rIL-2 2 単位/ $\mathrm{ml}$ を添加したェフェクター細胞を K562，Raji，T-24を標的細胞としてキラー活性を(4)と 同じ方法で測定した。

測定結果では培養時間の経過とともにキラー活性が 増強し, K562では20時間後, Raji, T-24では96時間後 にほとんどプラトーに達した。この結果から K562で は20時間後，Raji，T-24では96時間後の測定値を用い た.

(6) リンパ球サブセットの測定

モノクローナル抗体は CD3(OKT3), CD4(OKT4), CD8 (OKT8 : 以上 Ortho Pharmaceutical, Raritan, NJ), Leu7, CD16 (Leu11 : Becton Dickinson, Sunnyvale, CA), NKH-1(Coulter)を用いた。各モノク ローナル抗体を末梢血単核細胞に加え, $4{ }^{\circ} \mathrm{C}$ 暗所で30 分反応させた後, リン酸緩衝液 (phosphate buffered saline) で洗浄し, Epics V flow cytometer (Coulter Electronics, Hialeah, FL) にて測定した.

(7) 統計的解析

有意差検定は, Student $の \mathrm{t}$ 検定法を用い, 有意水準 は0.05とした。

\section{結 果}

(1) 末梢血単核細胞の NK 活性

各種標的細胞に対する NK 活性の測定結果を図 1 に示す. K562に対する NK 活性は, 表在性膀胼癌患者 では浸潤性膀胼癌患者と対照健康人に比し有意に増加 していたが $(\mathrm{p}<0.05)$, 浸潤性膀脂癌患者と対照健康 人との間には有意差はなかった. Raji に対する NK 活 性はほとんどみられなかった。

T-24に対しては, 表在性膀朕癌患者では対照健康人 
図 1 末梢血単核細胞の NK 活性

表在性膀胱癌患者では K562，T-24に対して NK 活性が有意に増強している.

\section{NK活性}

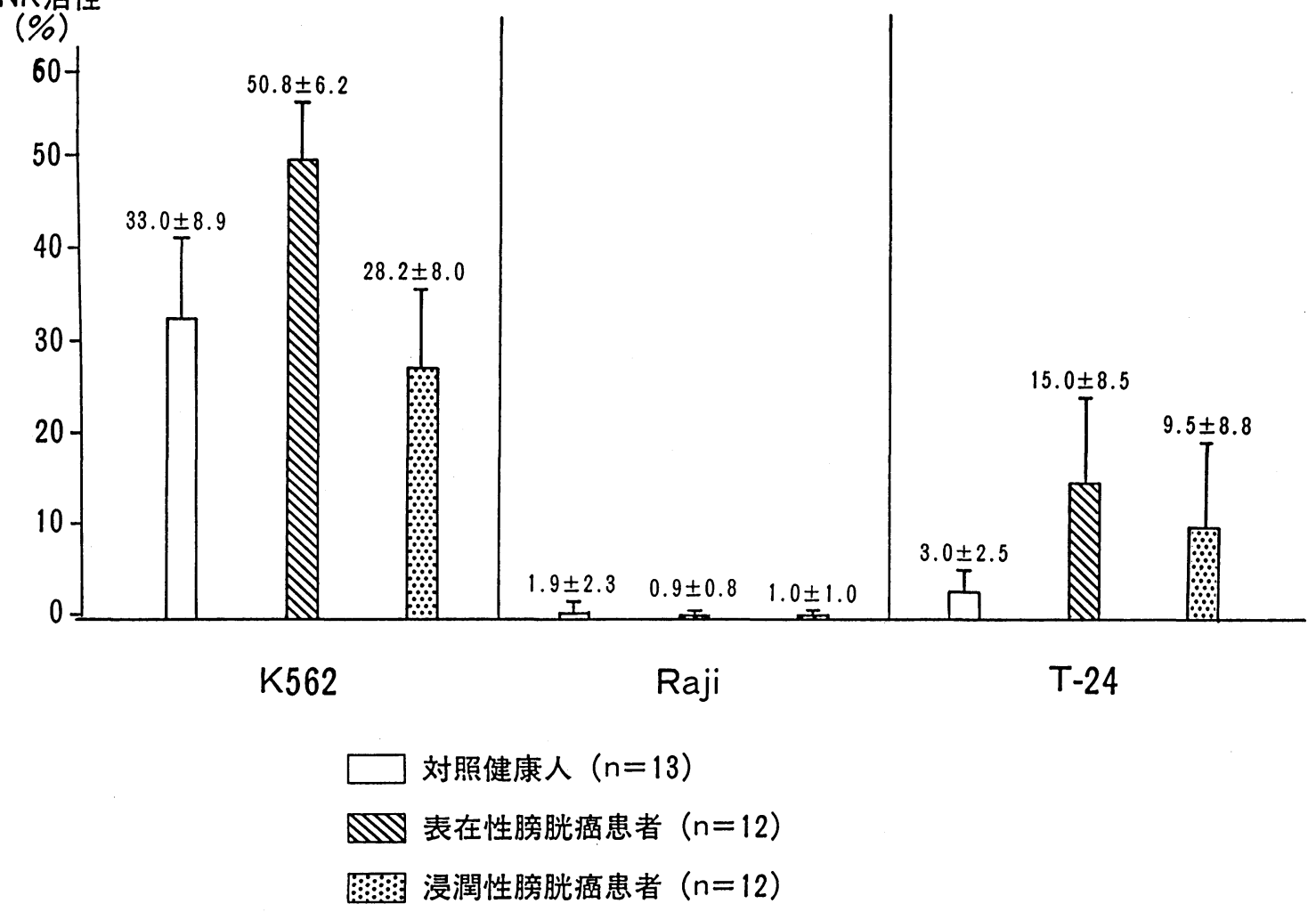

に比較して有意 $(\mathrm{p}<0.005)$ にK 活性は上昇してい たが, 浸潤性膀胱癌患者との間には有意差はなかった。 また浸潤性膀羘癌患者と対照健康人との間にも有意差 はみられなかった。

(2) 末梢血単核細胞の rIL-2添加によるキラー活性 の増強

測定結果を図 2 に示す. rIL-2添加による末梢血単核 細胞の K562, Raji, T-24に対するキラー活性は, 表在 性膀肤癌患者では著明に増強し, 浸潤性膀胱癌患者, 対照健康人に対して有意差を示した $(\mathrm{p}<0.05)$ ．浸潤 性膀脱癌患者と対照健康人との間に有意差はみられな かった.

(3)リンパ球サブセットの比較

$\mathrm{CD} 3, \mathrm{CD} 4, \mathrm{CD} 8$, Leu7, CD16，NKH-1とも表在性 および浸潤性腫崵間に有意差を認めなかった（表 1 ）。

\section{考 察}

われわれの結果では，表在性腫場患者では対照健康 人および浸潤性腫瘍患者に比べて K562に対する NK
活性が有意に増強し，また対照健康人に比べ，T-24に 対する NK 活性が有意に増強していた。

表在性膀胱癌では, NK 活性が増強するといら報 告9), 健常人と变らないといら報告 ${ }^{10111}$ 打よび低下して いるという報告 ${ }^{12)}$ があるが, 測定法の相違 ${ }^{12)}$ や, 患者の 年龄, 性などの違いに基づくものであろう。癌発生初 期に一時的に末梢血 NK 活性が上昇し, 病期が進むに つれて低下するのではないかとの意見13)もある.

表在性膀胱癌は浸潤性膀胱癌と異なり転移すること はきわめて稀で臨床的には良性に近い。この理由は明 らかではないが，表在性腫場では腫瘍浸潤リンパ球に T 細胞が多いといら局所免疫能の増強を示唆する報 告もある ${ }^{14)}$ ．われわれの結果では，浸潤性腫場患者の NK 活性は健康人と同様であったが，対象とした患者 の多くが全身状態が良好な膀胱全摘手術前で，臨床的 に転移もない状態であったためと思われる。

$\mathrm{NK}$ 活性などに代表される全身的免疫能は癌患者で 低下している場合でも手術後に正常化することが観察 
図 2 末梢血単核細胞の rIL-2添加によるキラー活性の増強

表在性膀胱癌患者では K562, Raji, T-24のいずれに対しても，rIL-2添加培養後のキ ラー活性が有意に増強している。

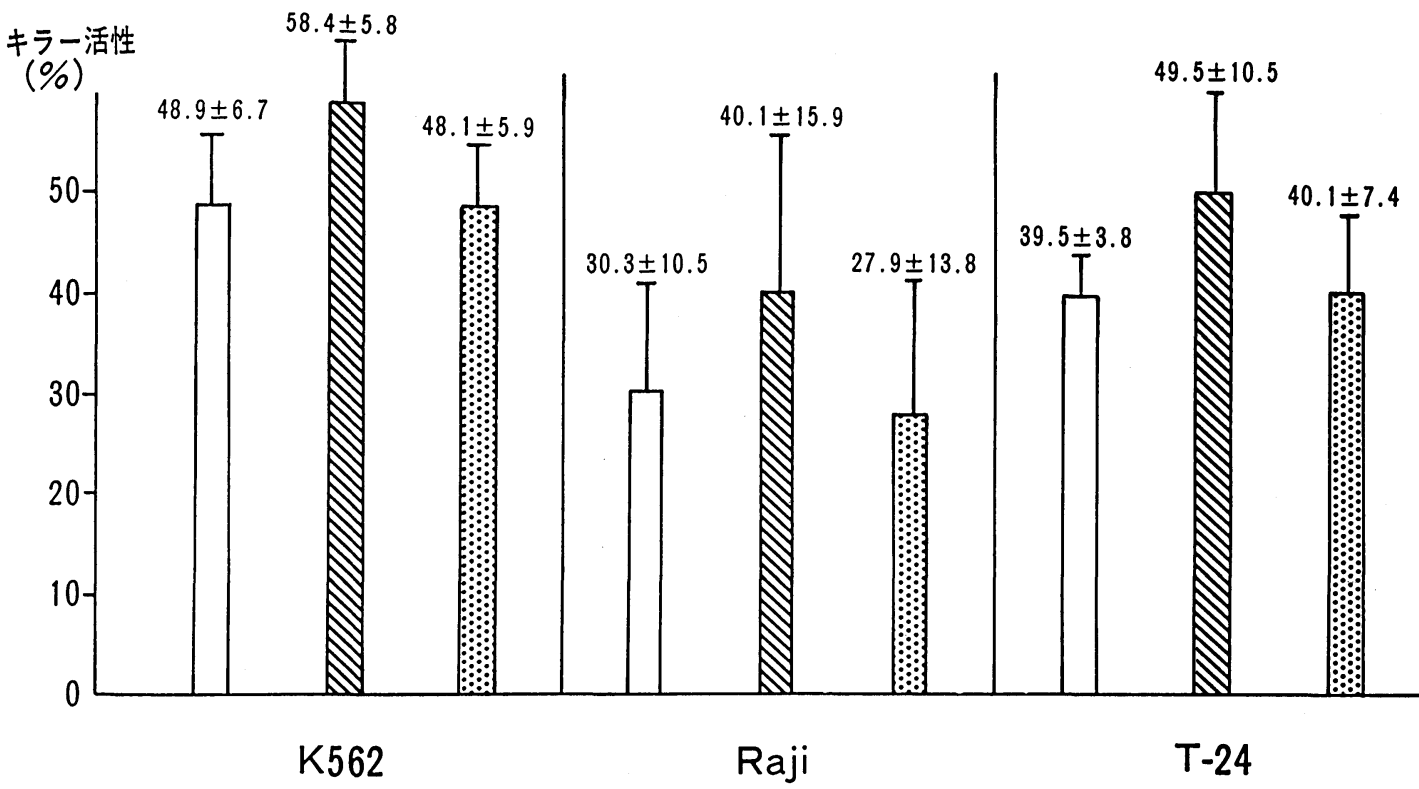

表 1 末梢血リンパ球サブセットの比較

\begin{tabular}{c|c|c}
\hline $\begin{array}{c}\text { モノク } \\
\text { ローナル 抗体 }\end{array}$ & $\begin{array}{c}\text { 表在性膀胱癌患者 } \\
(\mathrm{n}=12)\end{array}$ & $\begin{array}{c}\text { 浸潤性膀腅癌患者 } \\
(\mathrm{n}=12)\end{array}$ \\
\hline $\mathrm{CD} 3$ & $61.0 \pm 20.7 \%$ & $70.2 \pm 9.9 \%$ \\
\hline $\mathrm{CD} 4$ & $42.1 \pm 14.6 \%$ & $41.3 \pm 9.3 \%$ \\
\hline $\mathrm{CD} 8$ & $26.1 \pm 6.0 \%$ & $31.5 \pm 11.9 \%$ \\
\hline Leu 7 & $31.1 \pm 14.7 \%$ & $38.5 \pm 14.7 \%$ \\
\hline $\mathrm{CD} 16$ & $29.6 \pm 22.3 \%$ & $25.0 \pm 13.1 \%$ \\
\hline $\mathrm{NKH}-1$ & $25.9 \pm 13.6 \%$ & $24.5 \pm 11.7 \%$ \\
\hline \multicolumn{2}{|c}{} & $*$ mean $\pm \mathrm{SD}$
\end{tabular}

されており ${ }^{10)}$ ，担癌状態が全身的免疫能を抑制してい るとされている、癌末期では全身的免疫能は低下する ことが多(10)12)15) 17). また動物実験では NK 細胞の减 少した状態では有意に転移が起りやすくなることも知 られている1819).

若年者に表在性膀脱癌がみられることは稀である
が，その場合には比較的予後は良好であるとされ，こ れは若年者にみられる消化器などの癌が急速に進行 し，極めて予後不良であることが多いといら事実と異 なっている．NK 活性が増強している事実から表在性 膀胼癌患者に怙いては癌の進行が免疫監視機構之密接 な関連があることが強く示唆される. T-24は腫瘍特異 抗原を有する腫瘍といわれている，膀胱癌患者の $58 \%$ は末梢血リンパ球が T-24に対して細胞傷害性を示す が, 健常人では $5 \%$ の人でのみ T-24に対して細胞傷害 性を示すとされている6).われわれの結果でも表在性 膀胱癌患者では健康人よりも T-24に対する NK 活性 が有意に高かった，表在性膀胱癌患者ではマク口 ファージによる抗原提示がより強く行なわれ，リンパ 球の感作が既に成立している可能性がある ${ }^{20)}$. さらに 表在性膀胼癌患者ではある種のサイトカインが既に誘 導されている可能性も考えられる。

リンパ球表面マーカーの測定結果からは，表在性膀 胱癌と浸潤性膀胱癌および健常人の間に差がみられな 
かったが，このことはNK 活性の差異がリンパ球分画 の差によるものでないことを示している。一般に rIL2添加培養により癌末期患者リンパ球からでもいわゆ る Lymphokine activated killer (LAK) 細胞の誘導 が可能である ${ }^{8)}$. われわれの結果で, 表在性膀胱癌患者 に怙いてより高いキラー活性誘導が可能であったこと は, 表在性膀胀癌患者に対する rIL-2投与が有効であ る可能性を示唆するものと思われる。

\section{結語}

末梢血単核細胞の NK 活性および rIL-2添加培養に よるキラー活性の増強を表在性膀脂癌患者と浸潤性膀 脱癌患者の間で比較したところ, 表在性膀脱癌では健 常人および浸潤性膀胱癌に比べ K562に対する NK 活 性が，また健常人に比べT-24に対する NK 活性が有 意に増強しており, rIL-2添加培養後の K562, Raji お よびT-24に対するキラー活性の誘導も著明であった。 表在性膀胱癌患者と浸潤性膀胼癌患者の間にリンパ球 表面マーカーの差異はみられなかった。これらの結果 から膀胀腫瘍の進行, 治癒機転に抗腫瘍免度が関与し ていることが示唆される。

稿を終わるにあたり, 御指導をいただいた本学小児科学 講師川合 博博士とリンハ球表面マーカーの測定に御協力 いただいた輸血部伊藤 進技官, 本研究に協力して頂いた 泌尿器科学教室の諸先生に心より感謝いたします。

\section{文献}

1) Morales, A., Edinger, D. and Bruce, A.W.: Intracavitary bacillus calmette-guerin in the treatment of superficial bladder Tumors. J. Urol., 116, 180-183, 1976.

2) 早川正道, 秦野 直, 斎藤史郎, 宮里朝矩, 仲山 實, 五十嵐正道, 才田博幸：表在性膀脱腫場に対寸 る BCG 膀脂内注入療法一BCG 局所療法による宿 主の免疫反応一. 日泌尿会誌, 78, 1972-1981, 1987.

3）赤座英之, 亀山周二, 小磯謙吉, 垣添忠生, 小島弘 敬, 梅田 隆, 河辺香月, 藤田公生, 西村洋司, 横 山正夫, 河村 毅, 三方律治, 石井泰憲, 中内浩二, 藤 博, 木下健二, 岸 洋一, 原徹, 阿曾佳 郎, 新島端夫：膀胼移行上皮内癌㧍よび表在性膀 胱腫場に対する BCG (Tokyo 172株) 膀胱内注入 療法効果の解析. 日泌尿会誌, 80, 167-174, 1989.

4) Haaff, E.O., Catalona, W.J. and Ratliff, T.L.: Detection of interleukin 2 in the urine of patients with superficial bladder tumors after treatment with intravesical BCG. J. Urol., 136, 970-974, 1986.

5）橘政昭, 実川正道, 出口修宏, 田崎 寛: 膀胖腫
隍に対する BCG 膀脱内注入療法における宿主免 疫応答の賦活化に関する研究. 日泌尿会誌, 79, 1680-1685, 1988.

6) Bubenik, J., Baresova, M., Viklicky, V., Jakoubkova, J., Sainerova, H. and Donner, J. : Established cell line of urinary bladder carcinoma (T24) containing tumor-specific antigen. Int. J. Cancer, 11, 765-773, 1973.

7) Kiessling, R., Klein, E. and Wigzell, H.: "Natural" killer cells in the mouse. 1. Cytotoxic cells with specificity for mouse moloney leukemia cells. Specificity and distribution according to genotype. Eur. J. Immunol., 5, 112-117, 1975.

8) Grimm, E.A., Mazumder, A., Zhang, H.Z. and Rosenberg, S.A.: Lymphokine-activated killer cell phenomenon. Lysis of natural killerresistant fresh solid tumor cells by interleukin 2-activated autologous human peripheral blood lymphocytes. J. Exp. Med., 155, 1823-1841, 1982.

9) 深沢 潔：泌尿生殖器系担癌患者に招ける Natural killer 細胞活性の検討一各種癌疾患の進行度 と抗腫煌療法より観た Natural killer 細胞活性の 検討一。 日泌尿会誌, 79, 239-245，1988.

10) Ma, C.P., Yu, D.S., Yeh, M.Y., Chang, S.Y. and Han, S.H.: Natural killer cell activity in patients with urologic cancer. Eur. Urol., 13, 397-400, 1987.

11）辻橋宏典：膀朕腫場の宿主機構に関する研究. 膀 胖腫場組織浸潤リンパ球の免疫能に関する研究。 日泌尿会誌, 79, 977-984, 1988.

12) Morales, A., Facs, F. and Ottenhof, P.C.: Clinical application of a whole blood assay for human natural killer (NK) cell activity. Cancer, 52, 667-670, 1983.

13）山下元幸, 亀井義広, 藤田幸利: 尿路性器悪性腫場 患者の末梢血および領域リンパ節における natural killer (NK) 活性に関する研究. 1. 尿路性器 悪性腫瘍患者の末梢血 NK 活性に関する研究. 日 泌尿会誌，80，659-665, 1989.

14）辻橋宏典, 大西規夫, 秋山隆弘, 栗田 孝, 上島成 也 : 膀腅癌の宿主機構に関する研究. 膀胖腫瘍組 織浸潤リンパ球の免度組織学的検討. 日泌尿会誌, 78, 2140-2146, 1987.

15) Lotzova, E.: Several aspect of natural killer cell-mediated cytotoxicity in normal individuals and cancer patients. Cellular Molecular Biology, 26, 423-431, 1980.

16) Pross, H.F. and Boines, M.G.: Spontaneous human lymphocyte mediated cytotoxicity against tumor cells. 1 . The effect of malignant disease. Int. J. Cancer, 18, 593-604, 1976. 
17) Takasuki, M., Ramseyer, A. and Takasugi, J. : Decline of natural nonselective cell-mediated cytotoxicity in patients with tumor progression. Cancer Res., 37, 413-418, 1977.

18) Hanna, N.: Role of natural killer cells in host defence against cancer metastasis. in Cancer Invasion and Metastasis: Biologic and Therapeutic Aspects. Ed. by Nicolson, G.L. and Milas, L., New York, Raven Press, p. 309-319, 1984.

19) Gorelic, E., Wiltrout, R.H., Okumura, K., et al. : Role of NK cells in the control of metastatic spread and growth of tumor cells in mice. Int. J. Cancer, 30, 107-112, 1982.

20) Sakamoto, K., Yoshioka, T., Shimizu, J., Sato, S., Nakajima, H., Fujiwara, H. and Hamaoka, T.: Role of tumor-specific Lyt-2 ${ }^{+} \mathrm{T}$ cells in tumor growth inhibition in vivo. II. Mechanisms for recognition of tumor antigens and mediation of anti-tumor effect by noncytolytic Lyt-2+ T cell subset. Jpn. J. Cancer. Res., 79, 91-108, 1988.

（1989年11月15日受理） 